\title{
THE LOW ROTATION 1 PHASE AC GENERATOR USING MULTIPLE STATOR AND ROTOR METHOD IN THE FLOATING- HYDRO POWER PLANT
}

\author{
Ahmad Afif Amrulloh, Basuki Winarno, Yuli Prasetyo, Raden Jasa Kusumo Haryo
}

\begin{abstract}
Electrical energy is the most vital necessity in daily human's life. The need of electrical energy has been continuously increasing along with the industry and society development. Indonesia is a tropical country with loads of energy sources which one of them is the new renewable energy sources. There are still many unexploited river flows that possess potentials as energy sources. The Floating-Hydro power plant is one of portable power plants harnessing the river flows as the energy source. In this study, the Low Rotation 1 Phase AC Generator Using Multiple Stator and Rotor Method in the Floating-Hydro Power Plant was designed. This generator consisted of several stators and rotors. The stator was strung together using the enamel wire. As in accordance to the design outcome, the number of stator windings was 364 per coil, the space between windings was $4 \mathrm{~cm}$, and the stator diameter was $25 \mathrm{~cm}$. Meanwhile, the rotor consisted of Neodymium (NdFeB) type permanent magnet which was going to be induced into the stator. Every rotor consisted of 10 pieces of permanent magnet with a space between magnets was $2 \mathrm{~cm}$. The experiment result, which was performed on the 1 phase axial generator using 2 stators and 3 rotors with loads in the form of 3 pieces of $35 \mathrm{~W} 12 \mathrm{VAC}$ lamps, generated voltages of $2,1 \mathrm{VAC}$ with currents of $0,03 \mathrm{~A}$ at the low speed of $100 \mathrm{rpm}$. Meanwhile, at the speed of $1200 \mathrm{rpm}$, it generated voltages of $10,68 \mathrm{VAC}$ with currents of $0,23 \mathrm{~A}$.
\end{abstract}

Index Terms - Axial Flux Axial, Multiple Stator, Floating-Hydro, Permanent Magnet Neodymium (NdFeB).

\section{INTRODUCTION}

$\mathrm{E}$ VERY year, the need of electrical energy is increasing along with the industry and world civilization development. The average projection of growth in electricity need per year for 2018-2027 period

Ahmad Afif Amrulloh is an electrical engineering student, State Polytechnic of Madiun, Madiun, Indonesia (Phone 081554553616) email: afif.amrulloh17@gmail.com)

Basuki Winarno is a lecturer in the Electrical Engineering program of State Polytechnic of Madiun, Madiun, Indonesia (phone 085335410555; email basuki@pnm.ac.id)

Yuli Prasetyo is a lecturer in the Electrical Engineering program of State Polytechnic of Madiun, Madiun, Indonesia (phone 085336945185; email yuliprasetyo2224@pnm.ac.id)

Raden Jasa Kusumo Haryo is a lecturer in the Electrical Engineering program of State Polytechnic of Madiun, Madiun, Indonesia (phone 08883701002; email jasakusumo@pnm.ac.id) has been declined compared with 2017-2026 period, from $8,3 \%$ to $6,86 \%$. This is based on The Electricity Supply Business Plan (Rencana Usaha Penyediaan Tenaga Listrik) which was drew up by PT. Perusahaan Listrik Negara (State Electricity Company, Ltd.) on 2018-2026. That business plan had already been approved by Kementerian Energi dan Sumber Daya Mineral (The Ministry of Energy and Mineral Resources).

Indonesia is a tropical country with loads of energy sources which one of them is the new renewable energy sources. The water energy is one of the abundant energy in Indonesia. There are still many unexploited river flows that possess potential as energy sources. Based on the data of river flow volume in East Java on 2016, the area of river flow drainage zone was $162 \mathrm{~km}$ and its water volume touched $26(\mathrm{~m} 3 / \mathrm{sec})$. The electricity power plant using Floating-Hydro is one of the renewable electrical energy whereas this power plant only harnesses the river flow as a turbine motor thus the turbine rotates and set the rotor in motion from its generator from which the electrical energy produces.

In order to optimize the available potential, it requires a simple generator design to generate a small scale of electrical energy. The 1 phase generator of axial type permanent magnet is one of the types of alternative generator which is able to be developed as a FloatingHydro type generator.

\section{II.DESIGNING THE GENERATOR}

\section{A. Designing the Rotor}

In designing the rotor, it began firstly by determining the number of poles with the equation (1).

$$
P=\frac{120 \times f}{n}
$$

With $P$ is the number of poles, $f$ is the frequency, and $n$ is the rotor rotation. Based on several references, the rotor rotation calculation must be reduced by $0,5 \mathrm{x}$. The rotor was designed to work in rotations of 300rpm thus $\mathrm{n}$ in the amount of 600 was obtained. The equation for the rotor circumference is shown as below.

$$
K r=\left(T_{f} \cdot p\right)+(a \cdot p)
$$


With $\mathrm{Kr}$ is the rotor's circumference, a is the magnet width, and Tf is the space between magnets. The rotor thickness followed the magnet thickness that was being used. The rotor design is depicted in Figure 1.

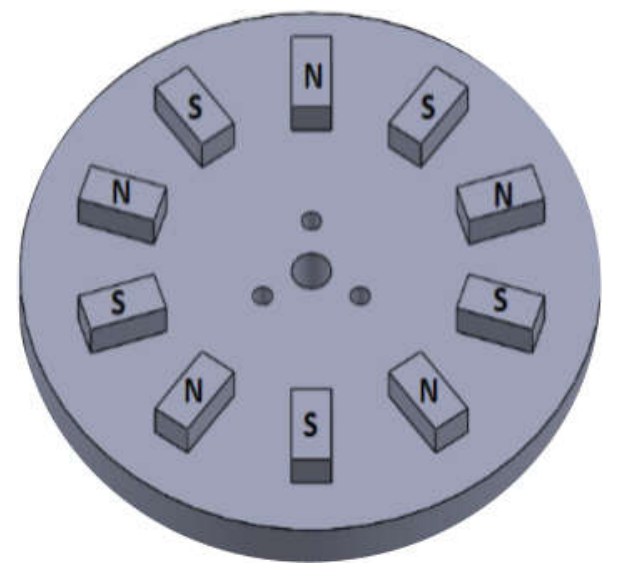

Figure. 1. Rotor Design

\section{B. Designing the Stator}

In designing the stator, the calculation for the number of coils used the equation 3 .

$$
N_{s}=P x \frac{N_{p h}}{2}
$$

With $N_{s}$ is the number of coils, $P$ is the number of poles, and $N_{p h}$ is the number of phases. The following equation 4 was used in order to determine the number of windings.

$$
E_{r m s}=\frac{E_{\max }}{\sqrt{2}}=\frac{2 \pi}{\sqrt{2}} \cdot N \cdot f \cdot \emptyset_{\max } \cdot \frac{N_{s}}{N_{p h}}
$$

Based on several references, the calculation for the number of rotor coil windings must be increased by $2 \mathrm{x}$. The stator wa designed to work at $\mathrm{E}_{\mathrm{rms}} 12$ volt thus the number of 364 windings were obtained.

\section{The Generator Construction}

The multi stator and rotor construction is shown in Figure 2 and 3.

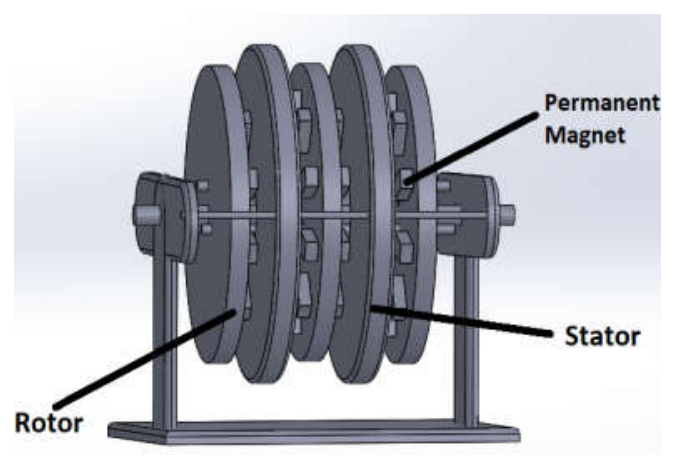

Figure. 2. Generator's Side View

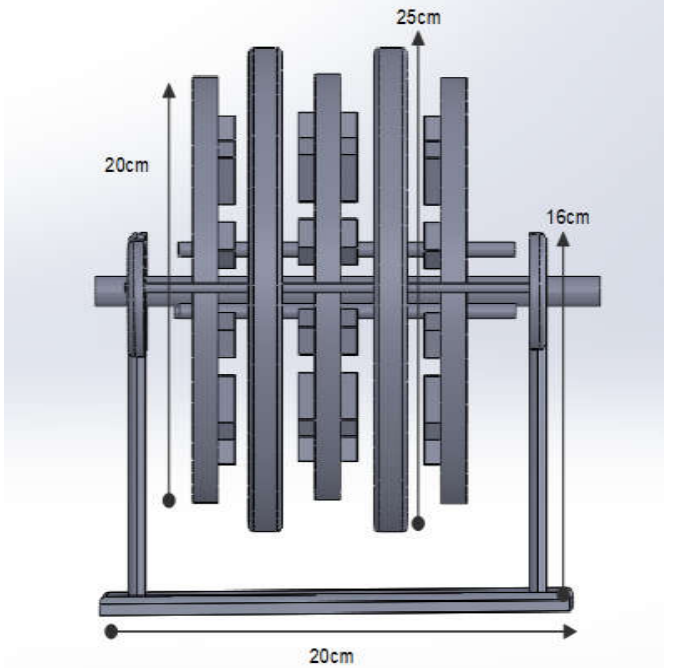

Figure. 3. Generator's Front View

\section{RESULT AND ANALYSIS}

\section{A. Manufacturing the Rotor}

Manufacturing the rotor was using Acrylic material which was cut to place the permanent magnet. Upon the installation of the permanent magnet, its South and North Pole must be taken into an account. In the event that S-S and N-N were clashing together, then the magnetic field is not going to be produced up to a point that magnetic field is going to disappear. The rotor construction is depicted in Figure 4.

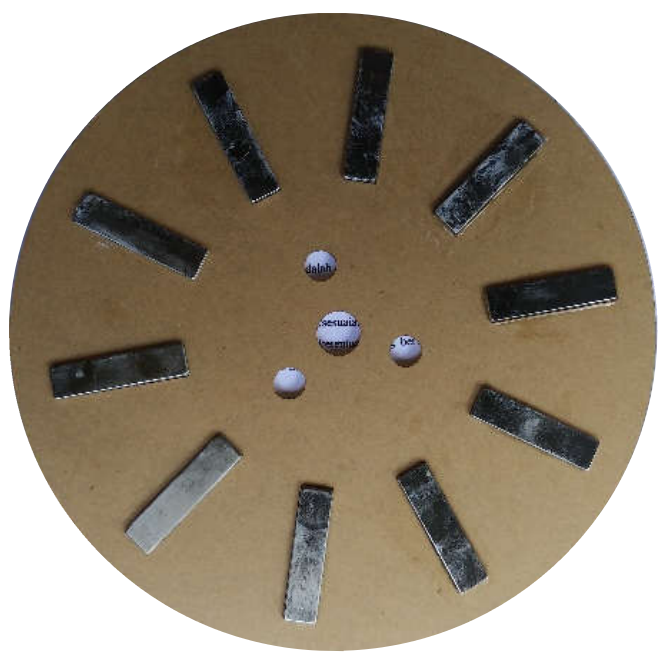

Figure. 4. Rotor

\section{B. Manufacturing the Stator}

The stator was made of enamel wires which were fasten up in accordance to the calculation. During the stator manufacturing, it required a stator mould which was made of wood that was coated by mirror glaze in order to ease up the stator discharge. The material used in creating the stator was made out of resin and catalyst. The stator mould is depicted in Figure 5 and the finished stator is in Figure 6. 


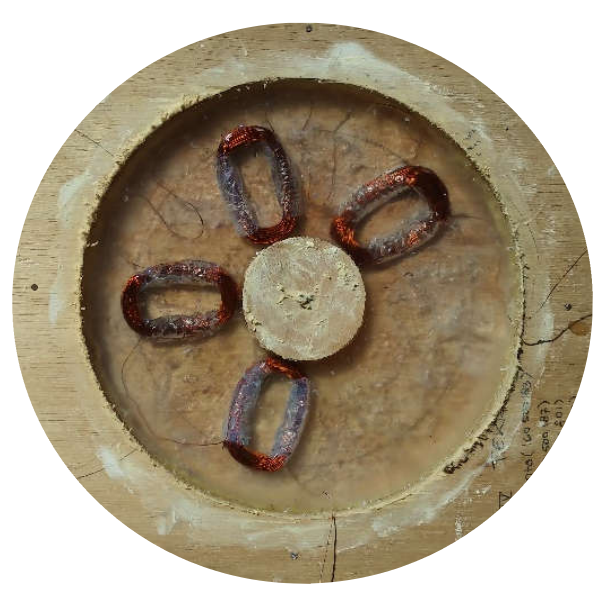

Figure. 5. Stator Mould

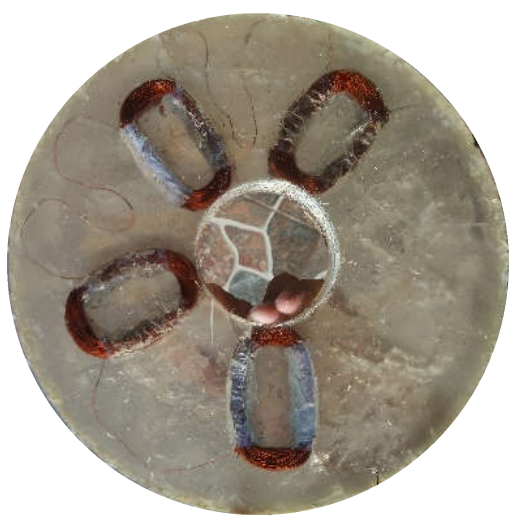

Figure. 6. Stator

\section{C.Assembling the Generator}

This generator used 3 rotors, 2 stators, the space between the stator and the rotor (air gap) was $0.5 \mathrm{~cm}$. The result of assembling the generator is depicted in Figure 7

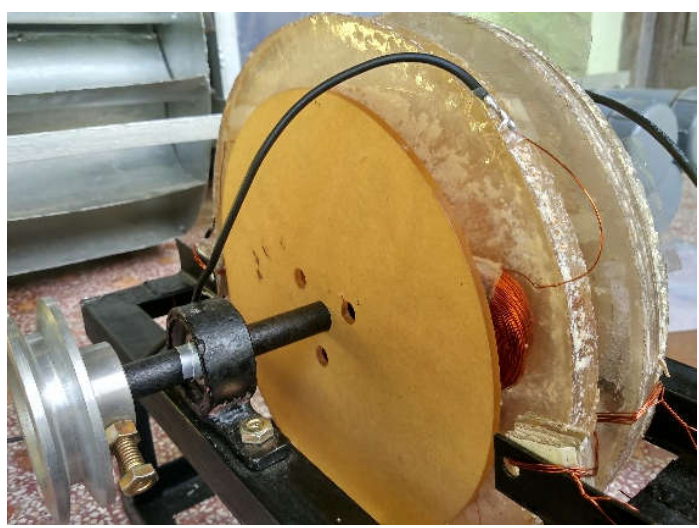

Figure. 7. The Generator

\section{D.Testing Out the Number Variation of Stator Coils}

The first step was to test the number of stator coils with the space between coils as $4 \mathrm{~cm}$, the number of windings was 364 per coil, the winding circumference was $0.5 \mathrm{~mm}$, to use 1 rotor, the number of permanent magnets was 10 pieces, the space between magnets was $2 \mathrm{~cm}$, the rotor circumference was $20 \mathrm{~cm}$, and the space between the stator and rotor (air gap) was $0.5 \mathrm{~cm}$. In this experiment, the number of coils that was being tested was 5 coils with the fixed space of $4 \mathrm{~cm}$. If the coil was more than 5, the space between coils was not fixed because it adjusted with the rotor circumference on where the permanent magnet glued. This experiment was carried out by utilizing the motor as an aid tool to rotate the generator. One of the other equipment used to test was a voltage regulator as the regulator of motor voltage, tachometer to measure the generator rotation, AVO meter to measure the voltage produced. The experiment result is depicted in Figure 8.

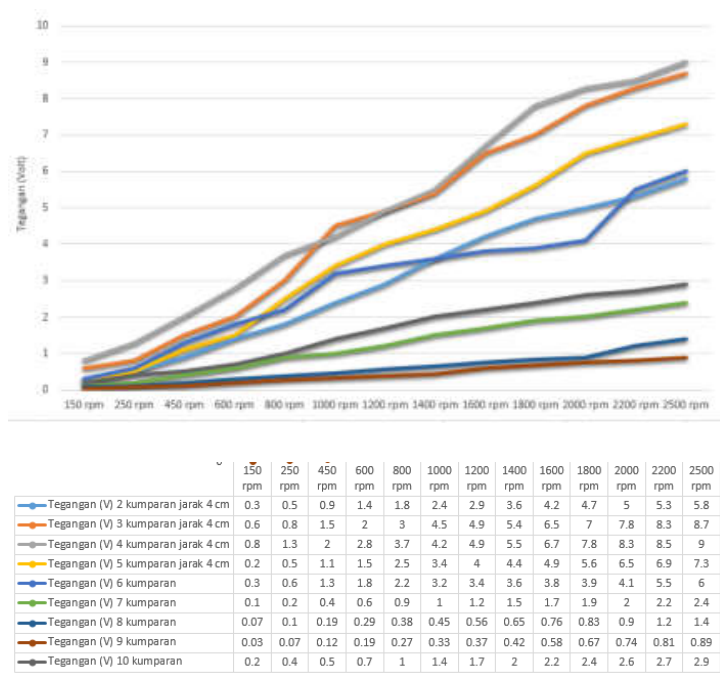

Figure. 8. The Results of All Test for Stator Coils

\section{E. Testing Out the Generator without Loads}

The experiment without loads on 1 phase axial generator used 2 stators and 3 rotors, the number of permanent magnet was 10 pieces per rotor, the number of coils was 4 per stator, the number of windings was 364 per coil, the windings circumference was $0.5 \mathrm{~mm}$, the space between the stator and rotor was $0.5 \mathrm{~cm}$, the space between coils was $4 \mathrm{~cm}$, and the space between permanent magnets was $2 \mathrm{~cm}$. The experiment was carried out by using the 1 phase AC motor to rotate the generator, the voltage regulator to regulate the $\mathrm{AC}$ motor voltage, tachometer to measure the generator rotation, AVO meter to measure the voltage produced is depicted in Figure 9.

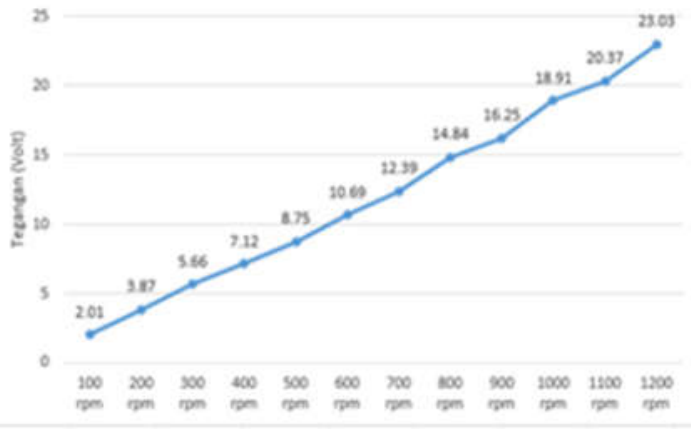

Figure. 9. The Test Result for Generator without Loads 


\section{F. Testing Out the Generator with Loads}

During the testing with loads of three 35 watt lamps, the 1 phase generator used 2 stators and 3 rotors with 10 permanent magnets per rotor, 4 coils per stator, 364 windings per coil, the winding circumference was 0.5 , the distance between stator and rotor was $0.5 \mathrm{~cm}$, the distance between coils was $4 \mathrm{~cm}$, and the distance between permanent magnets was $2 \mathrm{~cm}$. The testing was carried out by utilizing the 1 phase $\mathrm{AC}$ motor to rotate the generator, the voltage regulator to regulate the $\mathrm{AC}$ motor voltage, tachometer to measure the generator rotation, AVO meter to measure the voltage produced, the ampere pliers to measure the current is depicted in Figure 10.

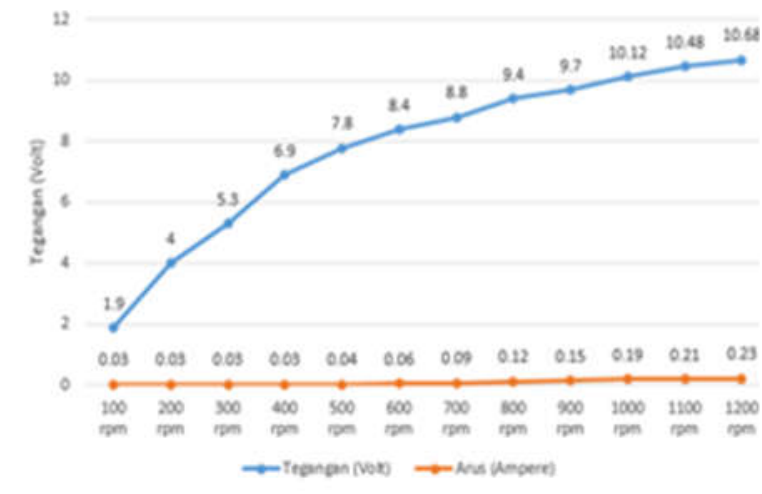

Figure. 10. The Test Result for Generator with Loads od 3 Lamps of 35 Watt AC

\section{CONCLUSIONS}

The experiment carried out on the 1 phase axial generator used 2 stators and 3 rotors with the loads in a form of 3 pieces of $35 \mathrm{~W} 12 \mathrm{VAC}$ lamps. The generator had the number of 364 windings per coil, the winding circumference was $0.5 \mathrm{~mm}$, the space between the stator and rotor was $0.5 \mathrm{~cm}$, the space between coils was $4 \mathrm{~cm}$, the space between the permanent magnet was $2 \mathrm{~cm}$, the stator diameter was $25 \mathrm{~cm}$, and the rotor diameter was $20 \mathrm{~cm}$. At the low speed of $100 \mathrm{rpm}$, it generated voltages of $2.1 \mathrm{VAC}$ with currents of $0.03 \mathrm{~A}$. Meanwhile, at the speed of $120 \mathrm{rpm}$, it generated voltages of $10.68 \mathrm{VAC}$ with currents of $0.23 \mathrm{~A}$.

\section{REFERENCES}

[1] Winarno, B., Haryo, J. K., \& Widodo, Y. H. (2019). Comparison of Stator Windings on Permanent Magnet Generators For Horizontal Axis Wind Turbine (Hawt). JEEMECS (Journal of Electrical Engineering, Mechatronic and Computer Science), 2(1), 53-56.

[2] Winarno, B., \& Yuwono, I. (2017). Optimalisasi Gaya pada Coil dengan Modifikasi Dimensi menggunakan Metoda Algoritma Genetika. JEECAE (Journal of Electrical, Electronics, Control, and Automotive Engineering), 2(1), 77-82.

[3] Puja Setia, Rozzef Pramana, S.T., M.T.(2017). Rancang Bangun Mini Generator Fluks Aksial 1 Fasa Putaran Rendah Menggunakan Neodymium Magnet (NdFeB) Berbasis Multi Cakram. Riau : Penerbit Universitas Maritim Raja Ali Haji

[4] Joko Arifin. Jurusan Teknik Politeknik Negeri (2017). Madiun Rancang Bangun Rangka dan Turbin Air Terapung pada Pembangkit Listrik Tenaga Floating Hydro-Portable (pdf)

[5] F. Danang Wijaya, Yusuf Susilo W, Ryan Adi Nugroho. (2014). Perancangan Generator Magnet Permanen Fluks Aksial Putaran Rendah. Yogyakarta : Penerbit Annual Engineering Seminar

[6] Sidik Nugroho. FT UMS. (2016). Desain Generator Magnet Permanen RPM Rendah dengan Memanfaatkan Motor Kipas. Skripsi

[7] Edy Sofian. FT UI (2011). Studi Bentuk Rotor Magnet Permanen Pada Generator Sinkron Magnet Permanen Fluks Aksial Tanpa Inti Stator Skripsi (pdf)

[8] Maulana Akbar. FT UI. (2012). Rancang Bangun Generator Turbin Angin Axial Tiga Fasa Untuk Kecepatan Angin Rendah. Skripsi 